\title{
Heavy metal contamination of some vegetables and spices in Nigeria
}

\author{
Chukwujindu M.A. IWEGBUE ${ }^{1 *}$, C. L. OVERAH ${ }^{1}$, J.K. EBIGWAI ${ }^{2}$, S.O. NWOZO ${ }^{3}$, \\ G.E. NWAJEI ${ }^{1}$ and Osa EGUAVOEN ${ }^{4}$ \\ ${ }^{1}$ Department of Chemistry, Delta State University, P.M.B 1 Abraka, Nigeria. \\ ${ }^{2}$ Department of Botany, University of Calabar, P.M.B 1115, Calabar, Nigeria. \\ ${ }^{3}$ Department of Biochemistry, University of Ibadan, Nigeria. \\ ${ }^{4}$ Department of Chemistry, Ambrose Alli University, P.M.B. 44, Ekpoma, Nigeria. \\ *Corresponding author,E-mail:maxipriestley@yahoo.com; jindumax@yahoo.com
}

\begin{abstract}
Analytical results are presented for the determination of $\mathrm{Cd}, \mathrm{Pb}, \mathrm{Cu}, \mathrm{Cr}, \mathrm{Ni}, \mathrm{Fe}$ and $\mathrm{Zn}$ contents in some species of fresh vegetables and spices (Abelmoschus esculentus, Amarathus spinosis, Cucumis sativa, Talinium triangulare, Daucus carrota, Phaseolus vulgaris, Vernonia amygdalina, Piper nigrum, Lycopersicon esculentum, Telfaria occidentalis, Cochorus olitorius, Allium cepa, Brassica oleraca Tephrosia densiflora, Capsicum annum, Citrullus vulgaris, Tetrapleura tetraptera, Anisophylea spp Piper guineensis, Mynstica fragrans, Aframomum melegueta and Allium sativum ) collected from markets in Warri and its environs (Nigeria) between February to May, 2007. The mean concentrations of these elements in vegetables and spices ranged from $0.01-11.5 \mathrm{mg} \cdot \mathrm{kg}^{-1}$ for $\mathrm{Pb}$; 0.01-0.2 mgkg ${ }^{-1}$ for $\mathrm{Cu}$; $0.17-4.2 \mathrm{mg} \cdot \mathrm{kg}^{-1}$ for $\mathrm{Cd}$, $0.01 \mathrm{mg} \cdot \mathrm{kg}^{-1}$ for $\mathrm{Cr}$; 0.01-16.8 mg. $\mathrm{kg}^{-1}$ for $\mathrm{Ni} ; 30-44.02 \mathrm{mg} \cdot \mathrm{kg}^{-1}$ for $\mathrm{Zn} ; 4.08-310.66 \mathrm{mg} \cdot \mathrm{kg}^{-1}$ for Fe. The results indicate that some of the vegetables and spices were contaminated with $\mathrm{Cd}$ and $\mathrm{Pb}$ and $\mathrm{Ni}$. More than $80 \%$ of the examined samples had concentrations of these metals below statutory safe limits.
\end{abstract}

() 2011 International Formulae Group. All rights reserved.

Keywords: Urban food safety, heavy metals, vegetables, spices, Nigeria.

\section{INTRODUCTION}

Urban food security in Nigeria is a matter of growing concern. It is estimated that a high percentage of Nigerians are living in urban area as well as an increasing proportion of the city dwellers are poor. Urban poverty is reflected in the nutritional status of the urban poor, whose intake of important nutrients frequently lies below the minimum recommended daily allowance. Over the past few decades, there has been a change in focus of nutritional health concern in Nigeria, from malnutrition, to wide spread chronic shortage of micronutrients and vitamins, particularly vitamin A whilst these deficiencies are not directly life threatened, they cause serious functional disorders. Women and children are particularly vulnerable.

In this context, it is particularly important to encourage the consumption of 
highly nutritious fruits and vegetable crops, but as the income elasticity of demand for these products tend to be high, there is a clear need to increase supply and maximize the nutritional quality of these products to benefit the poor. This is also acknowledged by Government of Nigeria policy, which recognizes long-term preventive need for sustained increased consumption of fresh vegetables and fruits rather distribution of iron and vitamin supplements. Whilst support for increased production and consumption of fresh vegetable is an important goal, citizen have a right to safe food and to be ensured that the fresh vegetable available to them are not contaminated beyond safe limits. Chemical contamination from sources such as industries, vehicles and pesticides can affect the safety of food. Heavy metals are one of a range of important type of contaminants that can be found on the surface and in the tissue of fresh vegetables, concentrations of heavy metals in foodstuffs may lead to the disruption of numerous biological and biochemical processes in human body. Heavy metals accumulation give rise to toxic concentrations in the body, while some elements (e.g. arsenic, cadmium, chromium) act as carcinogen and others (e.g. mercury and lead) are associated with developmental abnormalities in children (Abou-Arab et al., 1996).

Vegetable crops are often grown in polluted and degraded environmental conditions in the peri-urban (or urban fringe) zones are further subjected to pollution from vehicles and industries during marketing. This is therefore significant cause for concern regarding contamination. The primary objective of the present study was to determine the total concentration of $\mathrm{Cd}, \mathrm{Pb}$, $\mathrm{Ni}, \mathrm{Cu}, \mathrm{Cr}, \mathrm{Zn}$ and $\mathrm{Fe}$ in some vegetables and spices collected in urban markets in southern Nigeria with a view to provide information on hygienic and toxicological aspect.

\section{MATERIALS AND METHODS Sampling and analysis}

Fresh vegetables and spices samples were collected from different markets in Warri metropolis between February to May 2007 , to assess the heavy metal contamination of vegetables and spices currently being purchased in Warri markets. Twenty-two species were considered (Table I \& 2). The samples were washed with running tap water and finally rinsed with distilled water. The samples were dried by forced aeration supplied by industrial fan. The vegetables were immediately ground to wet paste using electrical blender. The spices were ground into fine powders.

A quantity of $2.00 \mathrm{~g}$ of the sample was placed in digestion tube and $10 \mathrm{ml}$ of nitric acid was then added and digested at $120^{\circ} \mathrm{C}$ until the liquor was clear. Next, $10 \mathrm{ml}$ of nitric acid and $2 \mathrm{ml}$ of perchioric acid were added and temperature was maintained at $120{ }^{\circ} \mathrm{C}$ for $1 \mathrm{~h}$ until the liquor become colorless. The digested liquor was filtered through Whatman No 1 filter paper and diluted to $20 \mathrm{ml}$ with double distilled water (Tarley et al., 2001). The digest was analyzed for $\mathrm{Cd}, \mathrm{Pb}, \mathrm{Cu}, \mathrm{Ni}$, $\mathrm{Zn}, \mathrm{Cr}$ and $\mathrm{Fe}$ using an atomic absorption spectrophotometry (GBC scientific equipment Sens AA, Melbourne, Australia) equipped with deuterium background correction devices.

In all metal determination, analytical blanks were prepared in a similar manner and were used to correct all instrument readings. All samples were run in triplicate and the coefficient of variation between triplicate analyses was less than 4\%. All glassware's were carefully cleaned with a solution of $10 \%$ nitric acid for $48 \mathrm{~h}$ followed by thorough rinsing with deionized water. The analytical procedure was checked using a spike recovery method (SRM). Some of the already analyzed samples were spiked with known concentrations of the metals and reanalyzed; 
the spike recovery for the metals was greater than $89 \%$ for all metals.

\section{RESULTS AND DISCUSSION}

The results for the determination of $\mathrm{Cd}$, $\mathrm{Pb}, \mathrm{Cu}, \mathrm{Cr}, \mathrm{Ni}, \mathrm{Fe}$ and $\mathrm{Zn}$ in vegetables and spices are presented in Tables 1 and 2, respectively. The values in parenthesis represent concentration ranges. Statistical analysis revealed that differences found in the contamination levels among the vegetables and spices are significant at $95 \%$ probability level except for chromium and copper. As a result we emphasize the importance of species factor in the accumulation of heavy metals and the place of origin, within the same vegetable species; differences in levels of contamination in the different anatomical parts have been noted (Zurera et al., 1987). Contamination of vegetables arises from difference in levels of the metals in soil where the vegetables are grown, irrigation water and variability in tendency to absorb physiologically toxic metals. Dosumu et al. (2003) reported high concentrations of metal water used to irrigate vegetables in western Nigeria (e.g. 0.12 - $10.98 \mathrm{mg} \mathrm{Ni} \mathrm{L} \mathrm{L}^{-1}$ and 0.1 $\left.3.48 \mathrm{mg} \mathrm{Cd} \mathrm{L}^{-1}\right)$.

The mean concentrations of lead in the vegetables and spices ranged from 0.01-11.5 mg. $\mathrm{kg}^{-1}$. The high mean levels of lead was observed, in the following spices; Tetrapleura tetraptera, (11.4 mg. $\left.\mathrm{kg}^{-1}\right) \quad$ Tephrosia densiflora (4.2 mg. $\mathrm{kg}^{-1}$ ), Allium sativum (3.0 mg. $\mathrm{kg}^{-1}$ ), Phaseolus vulgaris, (4.3 mg. $\left.\mathrm{kg}^{-1}\right)$ Mynstica fragrans (5.3 mg. $\left.\mathrm{kg}^{-1}\right)$ and Citrullus vulgaris $\quad\left(1.2 \quad \mathrm{mg} \cdot \mathrm{kg}^{-1}\right) . \quad$ The concentrations of $\mathrm{Pb}$ found in other species examined were relatively low and below the permissible limits for $\mathrm{Pb}$ in vegetable plants for consumption. The anomalous concentrations of $\mathrm{Pb}$ found in some species examined could be attributed to the fact that the vegetables are produced in gardens that are located close to well traveled roads or highway. The levels of $\mathrm{Pb}$ found in $74 \%$ of the samples examined are lower than concentrations of $\mathrm{Pb}$ in Amanranthus hybridus and Cochorus olitorius manni grown in western Nigeria (Dosumu et al., 2003). However $26 \%$ of samples had anomalously high levels of $\mathrm{Pb}$ compared to values reported by Dosumu et al. (2003) for Amanranthus hybridus and Cochorus olitorius manni. Exposure to lead has been associated with reduced IQ, learning disabilities, slow growth, hyperactive, anti social behaviors and impaired hearing, Lead is known to damage the kidney, liver and reproductive system, basic cellular processes and brain function (USEPA 1984, Dahiya et al., 2005). A provisional tolerable weekly intake has been established at $25 \mu \mathrm{g} / \mathrm{g}$ body weight (FOA/WHO, 1993).

Copper concentrations were relatively low in the samples examined. There was no significant intra and inter species difference at 95\% probability levels for the concentrations of copper observed in vegetable species. The mean levels of copper ranged from 0.01-2.12 mg. $\mathrm{kg}^{-1}$. The highest mean level of copper was observed in Citrullus vulgaris for the spices while Amarathus spnosis had the highest mean level of copper among the different vegetables. The levels of copper found in the vegetables and spices did not pose any contamination or health risk to consumers. Azcue et al. (1988) reported mean copper concentrations in the range of 0.17 $0.95 \mathrm{mg} \cdot \mathrm{kg}^{-1}$ for some vegetable food from Paraiba do sul River valley, Brazil. The concentrations of copper observed in this study were lower than this range. lyaka (2007) reported copper concentration in range of $1.6 \mathrm{mg} \cdot \mathrm{kg}^{-1}$ in Allium cepa to $3.0 \mathrm{mg} \cdot \mathrm{kg}^{-1}$ in okro (Abelmoschus esculentum). In India, Birla Singh et al. (2010) reported copper concentration ranging from $1.6 \mu \mathrm{g} / \mathrm{g}$ in Daucus carrota to $9.8 \mu \mathrm{g} / \mathrm{g}$ in onion (Allium сера). 
The mean concentrations of cadmium in spices ranged from $0.2 \mathrm{mg} \cdot \mathrm{kg}^{-1}$ Tephrosia densiflora to $0.7 \mathrm{mg} . \mathrm{kg}^{-1}$ in Allium sativum for spices and $0.3 \mathrm{mg} \cdot \mathrm{kg}^{-1}$ in Abelmoschus esculentum to $4.5 \mathrm{mg} \cdot \mathrm{kg}^{-1}$ in Daucus carrota for vegetables. Apart from carrots (Daucus carrota) that had significantly high levels of cadmium, all other samples have mean cadmium levels less than $0.8 \mathrm{mg} \mathrm{Cd} \mathrm{kg}^{-1}$. The levels of cadmium observed in this study are comparable to $0.3-1.2 \mathrm{mg} . \mathrm{kg}^{-1} \mathrm{Cd}$ reported in some vegetable varieties from different location in Ilorin, Nigeria (Dosumu et al., 2003). However, the levels of cadmium observed in our results were higher than concentrations of cadmium observed in some vegetable varieties in PSR valley, Brazil (Aczue et al., 1988). Cadmium concentrations of some medicinal plants studied in Italy, Egypt and Brazil were found in a wide range of $10-750 \mu \mathrm{g} \cdot \mathrm{kg}^{-1}, 50-300 \mu \mathrm{g} \cdot \mathrm{kg}^{-1}$ and $<0.2$ to $0.74 \mu \mathrm{g} . \mathrm{kg}^{-1}$ respectively (Abou-Arab et al., 1999; Caldas et al.., 2004; De Pasquale et al., 1999). Similarly, Ozkutlu et al. (2006) reported cadmium concentrations ranging from not detected in Mynstica fragrans to 206 $\mu \mathrm{g} . \mathrm{kg}^{-1}$ in Piper nigrum L. The vegetables and spices examined showed elevated metal compared to maximum allowable value of $0.05 \mathrm{mg} . \mathrm{kg}^{-1}$ in food. These vegetables and spices represent a route of exposure of cadmium to consumers.

The mean concentrations of nickel in vegetables and spices ranged from 0.01 - $16.8 \mathrm{mg} \cdot \mathrm{kg}^{-1}$ and $0.01-16.4 \mathrm{mg} \cdot \mathrm{kg}^{-1}$, respectively. The highest mean level of nickel was observed in cucumber (Cucumis sativum; $16.8 \mathrm{mgkg}^{-1}$ ). The following vegetables and spices varieties; Abelmoschus esculentus, Tephrosia densiflora, Capsicum nigrum, Cucumis sativum, Telfaria occidentalis and Mynstica fragrans had significant higher levels of nickel compared to any other vegetable examined. About $80 \%$ of the examined samples had nickel concentrations less than 0.02 mg. $\mathrm{kg}^{-1}$ Dosumu et al. (2003) observed in nickel levels ranging 0.4 to 3.2 mg. $\mathrm{kg}^{-1}$ in some vegetable varieties. However, $80 \%$ of the examined samples had nickel concentrations low than the range reported by Dosumu et al. (2003) and are comparable to levels reported for some vegetable food in PSR valley, Brazil (Aczue et al., 1998).

Chromium is relatively low in all the samples. There is no significant difference in levels of chromium in the vegetables and spices. The levels of chromium observed in these samples do not pose any contamination hazard to consumers. Similar low levels of chromium have been observed for some vegetable food in PSR valley, Brazil (Aczue et al., 1998).

The mean levels of zinc observed in vegetables and spices ranged from 3.3-44.0 mg. $\mathrm{kg}^{-1}$. The high levels of zinc were found in pumpkin leaf (Telfaria occidentalis) (44.0 $\mathrm{mgkg}^{-1}$ ) and Tephrosia densiflora (16.2 mg.kg$\left.{ }^{1}\right)$ for vegetables and spices, respectively. However, Vernonia amygdalina and Cochorus olitorius for examples showed relatively higher mean levels of zinc in comparison with other vegetable species studied. Ozkutlu et al. (2006) reported zinc concentration in some spices in Turkey in the range of $5.0 \mathrm{mg} \cdot \mathrm{kg}^{-1}$ in Pimenta dioica (L) Merri to $11.0 \mathrm{mg} \cdot \mathrm{kg}^{-1}$ in Alpinia officinarum and Piper nigrum (L). Zinc is an essential trace metal for plants, animals and human as it is associated with many enzymes and with certain proteins. The major health concern for zinc in general is marginal or deficient zinc intake rather than toxicity. Zinc is considered as being of low toxicity due to the wide margin between usual environmental concentrations and toxic levels. However, high levels of zinc are undesirable as it may lead to copper deficiency by inhibiting copper absorption. In this study, low levels of zinc were observed as compared with values reported for some Nigerian food items (Umar, 2004). The results indicate that bitter leaf (Vernonia amygdalina) is richer in zinc and iron concentrations compared to any 
C. M. A. IWEGBUE et al. / Int. J. Biol. Chem. Sci. 5(2): 766-773, 2011

Table 1: Mean concentrations of heavy metals in vegetables ( $\mathrm{mg} \cdot \mathrm{kg}^{-1}$ wet weight).

\begin{tabular}{|c|c|c|c|c|c|c|c|c|}
\hline Common name & Scientific name & $\mathbf{P b}$ & $\mathbf{C u}$ & Cd & $\mathbf{N i}$ & $\mathbf{Z n}$ & $\mathrm{Cr}$ & $\mathbf{F e}$ \\
\hline Okoro & Abelmoschus esculentus & $\begin{array}{l}0.01 \pm 0.00 \\
(0.01-0.01)\end{array}$ & $\begin{array}{l}0.01 \pm 0.00 \\
(0.01-0.01)\end{array}$ & $\begin{array}{l}0.3 \pm 0.3 \\
(0.01-0.6)\end{array}$ & $\begin{array}{l}3.2 \pm 3.0 \\
(0.01-5.9)\end{array}$ & $\begin{array}{l}7.0 \pm 1.8 \\
(5.5-9.0)\end{array}$ & $\begin{array}{l}0.01 \pm 0.00 \\
(0.01-0.01)\end{array}$ & $\begin{array}{l}29.9 \pm 12.8 \\
(14.9-37.2)\end{array}$ \\
\hline Green leaf & Amarathus spinosis & $\begin{array}{l}6.0 \pm 5.7 \\
(1.0-12.2)\end{array}$ & $\begin{array}{l}0.26 \pm 0.24 \\
(0.01-0.49)\end{array}$ & $\begin{array}{l}0.4 \pm 0.3 \\
(0.1-0.6)\end{array}$ & $\begin{array}{l}0.01 \pm 0.01 \\
(0.01-0.01)\end{array}$ & $\begin{array}{l}14.6 \pm 13.9 \\
(6.5 \pm 30.6)\end{array}$ & $\begin{array}{l}0.01 \pm 0.00 \\
(0.01-0.01)\end{array}$ & $\begin{array}{l}120.1 \pm 14.1 \\
(111.9-136.3)\end{array}$ \\
\hline Cucumber & Cucumis sativa & $\begin{array}{l}0.01 \pm 0.00 \\
(0.01-0.01)\end{array}$ & $\begin{array}{l}0.01 \pm 0.00 \\
(0.01-0.01)\end{array}$ & $\begin{array}{l}0.4 \pm 0.1 \\
(0.4-0.5)\end{array}$ & $\begin{array}{l}16.8 \pm 29.1 \\
(0.01-50.3)\end{array}$ & $\begin{array}{l}1.9 \pm 0.5 \\
(1.4-2.2)\end{array}$ & $\begin{array}{l}0.01 \pm 0.00 \\
(0.01-0.01)\end{array}$ & $\begin{array}{l}4.1 \pm 7.1 \\
(0.01-12.2)\end{array}$ \\
\hline Water leaf & Talinium triangulare & $\begin{array}{l}6.2 \pm 10.8 \\
(0.01-18.7)\end{array}$ & $\begin{array}{l}0.01 \pm 0.00 \\
(0.01-0.01)\end{array}$ & $\begin{array}{l}0.4 \pm 0.0 \\
(0.3-0.4)\end{array}$ & $\begin{array}{l}0.01 \pm 0.00 \\
(0.01-0.01)\end{array}$ & $\begin{array}{l}3.9 \pm 1.1 \\
(2.6-4.7)\end{array}$ & $\begin{array}{l}0.01 \pm 0.00 \\
(0.01-0.01)\end{array}$ & $\begin{array}{l}20.2 \pm 7.3 \\
(28.6-16.0)\end{array}$ \\
\hline Carrot & Daucus carrota & $\begin{array}{l}0.01 \pm 0.00 \\
(0.01-0.01)\end{array}$ & $\begin{array}{l}0.01 \pm 0.00 \\
(0.01-0.01)\end{array}$ & $\begin{array}{l}4.5 \pm 6.9 \\
(0.2-12.5)\end{array}$ & $\begin{array}{l}0.01 \pm 0.00 \\
(0.01-0.01)\end{array}$ & $\begin{array}{l}7.4 \pm 1.1 \\
(6.6-8.7)\end{array}$ & $\begin{array}{l}0.01 \pm 0.00 \\
(0.01-0.01)\end{array}$ & $\begin{array}{l}182.3 \pm 9.4 \\
(172.0-190.3)\end{array}$ \\
\hline Green beans & Phaseolus vulgaris & $\begin{array}{l}4.3 \pm 7.4 \\
(0.01-12.9)\end{array}$ & $\begin{array}{l}0.01 \pm 0.00 \\
(0.01-0.01)\end{array}$ & $\begin{array}{l}0.5 \pm 0.2 \\
(0.3-0.6)\end{array}$ & $\begin{array}{l}0.01 \pm 0.00 \\
(0.01-0.01)\end{array}$ & $\begin{array}{l}6.7 \pm 0.8 \\
(6.1-7.6)\end{array}$ & $\begin{array}{l}0.01 \pm 0.00 \\
(0.01-0.01)\end{array}$ & $\begin{array}{l}181.0 \pm 18.4 \\
(169.1-202.3)\end{array}$ \\
\hline Bitter leaf & Vernonia amygdalina & $\begin{array}{l}0.01 \pm 0.00 \\
(0.01-0.01)\end{array}$ & $\begin{array}{l}0.01 \pm 0.00 \\
(0.01-0.01)\end{array}$ & $\begin{array}{l}0.6 \pm 0.1 \\
(0.4-0.7)\end{array}$ & $\begin{array}{l}0.01 \pm 0.00 \\
(0.01-0.01)\end{array}$ & $\begin{array}{l}22.3 \pm 5.9 \\
(18.5-29.1)\end{array}$ & $\begin{array}{l}0.01 \pm 0.00 \\
(0.01-0.01)\end{array}$ & $\begin{array}{l}270.2 \pm 38.7 \\
(236.4-312.4)\end{array}$ \\
\hline Green paper & Piper nigrum & $\begin{array}{l}0.01 \pm 0.00 \\
(0.01-0.01)\end{array}$ & $\begin{array}{l}0.01 \pm 0.00 \\
(0.01-0.01)\end{array}$ & $\begin{array}{l}0.6 \pm 0.1 \\
(0.5-0.7)\end{array}$ & $\begin{array}{l}0.01 \pm 0.00 \\
(0.01-0.01)\end{array}$ & $\begin{array}{l}3.5 \pm 0.9 \\
(2.5-4.3)\end{array}$ & $\begin{array}{l}0.01 \pm 0.00 \\
(0.01-0.01)\end{array}$ & $\begin{array}{l}150.7 \pm 20.4 \\
(135.1-173.7)\end{array}$ \\
\hline Tomato & $\begin{array}{l}\text { Lycopersicon } \\
\text { esculentum }\end{array}$ & $\begin{array}{l}0.01 \pm 0.00 \\
(0.01-0.01)\end{array}$ & $\begin{array}{l}0.01 \pm 0.00 \\
(0.01-0.01)\end{array}$ & $\begin{array}{l}0.5 \pm 0.2 \\
(0.3-0.8)\end{array}$ & $\begin{array}{l}0.01 \pm 0.00 \\
(0.01-0.01)\end{array}$ & $\begin{array}{l}3.6 \pm 1.8 \\
(1.8-5.3)\end{array}$ & $\begin{array}{l}0.01 \pm 0.00 \\
(0.01-0.01)\end{array}$ & $\begin{array}{l}116.3 \pm 41.3 \\
(78.7-109.6)\end{array}$ \\
\hline Pumpkin leaf & Telfaria occidentalis & $\begin{array}{l}0.4 \pm 0.7 \\
(0.01-1.21)\end{array}$ & $\begin{array}{l}0.01 \pm 0.00 \\
(0.01-0.01)\end{array}$ & $\begin{array}{l}0.6 \pm 0.1 \\
(0.6-0.7)\end{array}$ & $\begin{array}{l}5.8 \pm 6.6 \\
(1.9-13.5)\end{array}$ & $\begin{array}{l}44.0 \pm 5.5 \\
(38.7-49.8)\end{array}$ & $\begin{array}{l}0.01 \pm 0.00 \\
(0.01-0.01)\end{array}$ & $\begin{array}{l}310.7 \pm 20.0 \\
(293.6-332.8)\end{array}$ \\
\hline Ewedu leaf** & Cochorus olitorius & $\begin{array}{l}3.3 \pm 5.7 \\
(0.01-9.8)\end{array}$ & $\begin{array}{l}0.01 \pm 0.00 \\
(0.01-0.01)\end{array}$ & $\begin{array}{l}0.8 \pm 0.3 \\
(0.5-1.1)\end{array}$ & $\begin{array}{l}0.01 \pm 0.00 \\
(0.01-0.01)\end{array}$ & $\begin{array}{l}21.2 \pm 8.1 \\
(16.2-30.6)\end{array}$ & $\begin{array}{l}0.01 \pm 0.00 \\
(0.01-0.01)\end{array}$ & $\begin{array}{l}160.3 \pm 11.1 \\
(153.0-173.0)\end{array}$ \\
\hline Onion & Allium сера & $\begin{array}{l}0.01 \pm 0.00 \\
(0.01-0.01)\end{array}$ & $\begin{array}{l}0.01 \pm 0.00 \\
(0.01-0.01)\end{array}$ & $\begin{array}{l}0.5 \pm 0.1 \\
(0.5-0.6)\end{array}$ & $\begin{array}{l}0.01 \pm 0.00 \\
(0.01-0.01)\end{array}$ & $\begin{array}{l}3.3 \pm 0.7 \\
(2.7-4.0)\end{array}$ & $\begin{array}{l}0.01 \pm 0.00 \\
(0.01-0.01)\end{array}$ & $\begin{array}{l}112.9 \pm 32.4 \\
(78.1-142.1)\end{array}$ \\
\hline Cabbage & Brassica oleraca & $\begin{array}{l}0.01 \pm 0.00 \\
(0.01-0.01)\end{array}$ & $\begin{array}{l}0.01 \pm 0.00 \\
(0.01-0.01)\end{array}$ & $\begin{array}{l}0.4 \pm 0.3 \\
(0.1-0.6)\end{array}$ & $\begin{array}{l}0.01 \pm 0.00 \\
(0.01-0.01)\end{array}$ & $\begin{array}{l}6.4 \pm 4.9 \\
(3.4-12.1)\end{array}$ & $\begin{array}{l}0.01 \pm 0.00 \\
(0.01-0.01)\end{array}$ & $\begin{array}{l}117.9 \pm 10.3 \\
(106.4-121.2)\end{array}$ \\
\hline
\end{tabular}

Values are means $\pm \mathrm{SD} ; \mathrm{n}=9 ; \quad * *$ Yoruba language 
C. M. A. IWEGBUE et al. / Int. J. Biol. Chem. Sci. 5(2): 766-773, 2011

Table 2: Mean concentrations of heavy metals in spices ( $\mathrm{mg} \cdot \mathrm{kg}^{-1}$ wet weight).

\begin{tabular}{|c|c|c|c|c|c|c|c|c|}
\hline Common name & Scientific name & $\mathbf{P b}$ & $\mathbf{C u}$ & Cd & $\mathrm{Ni}$ & Zn & $\mathbf{C r}$ & $\mathbf{F e}$ \\
\hline Benetiete & Tephrosia densiflora & $\begin{array}{l}4.2 \pm 1.8 \\
(0.0-5.6)\end{array}$ & $\begin{array}{l}0.01 \pm 0.00 \\
(0.01-0.01)\end{array}$ & $\begin{array}{l}0.2 \pm 0.2 \\
(0.01-0.3)\end{array}$ & $\begin{array}{l}5.1 \pm 5.7 \\
(0.01-11.4)\end{array}$ & $\begin{array}{l}16.3 \pm 1.9 \\
(14.5-18.2)\end{array}$ & $\begin{array}{l}0.01 \pm 0.00 \\
(0.01-0.01)\end{array}$ & $\begin{array}{l}302.5 \pm 60.3 \\
(253.6-369.9)\end{array}$ \\
\hline Pepper & Capsicum annum & $\begin{array}{l}0.01 \pm 0.00 \\
(0.01-0.01)\end{array}$ & $\begin{array}{l}0.01 \pm 0.00 \\
(0.01-0.01)\end{array}$ & $\begin{array}{l}0.2 \pm 0.2 \\
(0.01-0.4)\end{array}$ & $\begin{array}{l}16.4 \pm 28.4 \\
(0.01-49.1)\end{array}$ & $\begin{array}{l}13.6 \pm 2.1 \\
(11.8-15.9)\end{array}$ & $\begin{array}{l}0.01 \pm 0.00 \\
(0.01-0.01)\end{array}$ & $\begin{array}{l}15.3 \pm 11.9 \\
(5.5-28.5)\end{array}$ \\
\hline Melon seed & Citrullus vulgaris & $\begin{array}{l}1.3 \pm 2.0 \\
(0.01-3.6)\end{array}$ & $\begin{array}{l}2.1 \pm 0.5 \\
(1.8-2.6)\end{array}$ & $\begin{array}{l}0.4 \pm 0.3 \\
(0.1-0.7)\end{array}$ & $\begin{array}{l}0.08 \pm 0.13 \\
(0.01-0.23)\end{array}$ & $\begin{array}{l}15.8 \pm 18.0 \\
(7.6-36.4)\end{array}$ & $\begin{array}{l}0.01 \pm 0.00 \\
(0.01-0.01)\end{array}$ & $\begin{array}{l}15.3 \pm 11.9 \\
(5.5-28.5)\end{array}$ \\
\hline Uda* & Tetrapleura tetraptera & $\begin{array}{l}11.5 \pm 12.5 \\
(0.01-24.8)\end{array}$ & $\begin{array}{l}0.01 \pm 0.00 \\
(0.01-0.01)\end{array}$ & $\begin{array}{l}0.3 \pm 0.1 \\
(0.3-0.5)\end{array}$ & $\begin{array}{l}5.2 \pm 8.9 \\
(0.01-15.5)\end{array}$ & $\begin{array}{l}7.2 \pm 1.4 \\
(5.6-8.1)\end{array}$ & $\begin{array}{l}0.01 \pm 0.00 \\
(0.01-0.01)\end{array}$ & $\begin{array}{l}198.4 \pm 16.2 \\
(183.2-215.5)\end{array}$ \\
\hline Erhe $* * *$ & Anisophylea spp & $\begin{array}{l}0.01 \pm 0.00 \\
(0.01-0.01)\end{array}$ & $\begin{array}{l}0.05 \pm 0.08 \\
(0.01-0.14)\end{array}$ & $\begin{array}{l}0.4 \pm 0.4 \\
(0.01-0.9)\end{array}$ & $\begin{array}{l}0.01 \pm 0.00 \\
(0.01-0.01)\end{array}$ & $\begin{array}{l}10.2 \pm 1.3 \\
(9.5-11.7)\end{array}$ & $\begin{array}{l}0.01 \pm 0.00 \\
(0.01-0.01)\end{array}$ & $\begin{array}{l}215.0 \pm 11.6 \\
(201.7-224.2)\end{array}$ \\
\hline Eshasha*** & Piper guineensis & $\begin{array}{l}0.01 \pm 0.00 \\
(0.01-0.01)\end{array}$ & $\begin{array}{l}1.1 \pm 1.9 \\
(0.01-3.3)\end{array}$ & $\begin{array}{l}0.2 \pm 0.2 \\
(0.04-0.5)\end{array}$ & $\begin{array}{l}0.01 \pm 0.00 \\
(0.01-0.01)\end{array}$ & $\begin{array}{l}9.5 \pm 0.7 \\
(8.9-10.1)\end{array}$ & $\begin{array}{l}0.01 \pm 0.00 \\
(0.01-0.01)\end{array}$ & $\begin{array}{l}193.3 \pm 33.5 \\
(167.3-231.2)\end{array}$ \\
\hline Nutmeg & Mynstica fragrans & $\begin{array}{l}5.3 \pm 4.8 \\
(0.01-9.4)\end{array}$ & $\begin{array}{l}0.01 \pm 0.00 \\
(0.01-0.01)\end{array}$ & $\begin{array}{l}0.5 \pm 0.1 \\
(0.4-0.6)\end{array}$ & $\begin{array}{l}9.3 \pm 16.2 \\
(0.01-28.0)\end{array}$ & $\begin{array}{l}7.2 \pm 1.1 \\
(6.0-8.0)\end{array}$ & $\begin{array}{l}0.01 \pm 0.00 \\
(0.01-0.01)\end{array}$ & $\begin{array}{l}125.4 \pm 32.4 \\
(20.7-131.0)\end{array}$ \\
\hline Etaike*** & Aframomum melegueta & $\begin{array}{l}0.01 \pm 0.00 \\
(0.01-0.01)\end{array}$ & $\begin{array}{l}0.01 \pm 0.00 \\
(0.01-0.01)\end{array}$ & $\begin{array}{l}0.3 \pm 0.2 \\
(0.2-0.5)\end{array}$ & $\begin{array}{l}0.01 \pm 0.00 \\
(0.01-0.01)\end{array}$ & $\begin{array}{l}11.8 \pm 0.2 \\
(11.7-12.0)\end{array}$ & $\begin{array}{l}0.01 \pm 0.00 \\
(0.01-0.01)\end{array}$ & $\begin{array}{l}165.6 \pm 48.8 \\
(115.6-213.0)\end{array}$ \\
\hline Garlic & Allium sativum & $\begin{array}{l}3.0 \pm 5.2 \\
(0.01-9.1)\end{array}$ & $\begin{array}{l}0.01 \pm 0.00 \\
(0.01-0.01)\end{array}$ & $\begin{array}{l}0.7 \pm 0.3 \\
(0.4-1.0)\end{array}$ & $\begin{array}{l}0.01 \pm 0.00 \\
0.01-0.01\end{array}$ & $\begin{array}{l}10.5 \pm 1.0 \\
(9.4-11.4)\end{array}$ & $\begin{array}{l}0.01 \pm 0.00 \\
(0.01-0.01)\end{array}$ & $\begin{array}{l}13.2 \pm 2.6 \\
(10.2-14.7)\end{array}$ \\
\hline
\end{tabular}


other vegetables and spices. The concentrations of iron in the vegetable varieties ranged from $4.08 \mathrm{mg} \cdot \mathrm{kg}^{-1} \mathrm{Fe}$ in cucumber to $310 \mathrm{mg} \cdot \mathrm{kg}^{-1} \mathrm{Fe}$ in pumpkin leaf while for the spices the concentration ranged from $13.2 \mathrm{mg} \cdot \mathrm{kg}^{-1}$ in Allium sativum to 302.50 $\mathrm{mgkg}^{-1}$ in Tephrosia densiflora. The levels of iron and zinc observed in this study are high as compared to the levels reported for some vegetable varieties (Aczue et al., 1988; Dosumu et al., 2003). However, similar levels of iron have be reported for some Nigeria food items e.g. melon seeds (Citrullus vulgaris) (100.0 mg.kg-1), Okro (Abelmoschus esculentus) (5.59 mg. $\left.\mathrm{kg}^{-1}\right)$ and Spinach chenopodiaceace $\left(733.0 \mathrm{mg} \cdot \mathrm{kg}^{-1}\right)$ (Umar, 2004).

\section{Conclusion}

The results presented from this study indicate that concentrations of chromium, zinc, iron, and copper are present in all species examined in levels below statutory safety limit while cadmium, lead and nickel are present in some species at high concentrations. However, greater than eighty percent of the examined samples had concentration of cadmium, nickel and lead at levels below salutatory safety limits. The higher concentrations of $\mathrm{Cd}, \mathrm{Pb}$ and $\mathrm{Ni}$ in vegetables and spices in the market samples could be related to industrialization, automobile emission and related activities in these areas. The results of this study supply valuable information about the metal contents of vegetables and spices from internal markets around Warri and indirectly indicate the environmental contamination along the area. Moreover, these results can also be used to understand the chemical quality of vegetables and spices, and to evaluate the possible risk associated with their consumption.

\section{ACKNOWLEDGEMENTS}

The authors are grateful to Miss Onoriode Omomah and Miss Mary Jane Okehna for their assistance in sample collection, mailing and atomic absorption analysis in their laboratory.

\section{REFERENCES}

Abou-Arab AAK, Kawther MS, El-tantaway MF, Badeaa RI, Khayria N. 1999. Quantity estimation of some contaminants in commonly used medicinal plants in the Egyptian market. Food Chem., 67: 357 363.

Azcue JMP, Ofeiffer WC, Donangelo CM, Fiszman M, Maliu O. 1988. Heavy metals in food from Paraiba do sul River valley Brazil. J. Food Comp. Anal., 1: 250-258.

Birla Singh K, Taneja SK. 2010. Concentration of $\mathrm{Zn}, \mathrm{Cu}$ and $\mathrm{Mn}$ in vegetables and meats foodstuff commonly available in Manipur: North eastern State of India. E- J. Environ. Agric. Food Chem., 9(3): 610-616.

Caldas ED, Koyuncu M, Atay BA. 2004. Cadmium, mercury and lead in medicinal herbs in Brazil. Food and Chem. Toxicol., 42: 599-603.

Dahiya S, Karpe R, Hogde AG, Sharma RM. 2005. Lead, cadmium and nickel in chocolates and candies from suburban area of Mumbai, India. J. Food Comp. Anal., 18: 517-522.

De Pasquale A, Paino E, De Pasquale R, Germano MP. 1993. Contamination by heavy metals in drugs from different commercial sources. Pharm. Res., 27: 910.

Dosumu OO, Salami N, Adekola FA. 2003. Comparative study of trace clement levels in some local vegetable varieties and irrigation waters from different locations in Ilorin. Nigeria. Bull. Chem. Soc. Ethiop., 17(1): 107-112.

FAO/WHO. 1993. Evaluation of certain food additives and contaminants. WHO Technical Report Series, 837, Geneva.

Iyoka YA. 2007. Concentration of $\mathrm{Cu}$ and $\mathrm{Zn}$ in some fruit and vegetables commonly available in North-central zone of Nigeria. 
E- J. Environ. Agric. Food Chem., 6(6): 2150-2154.

Kocak S, Tokusoglu O, Ayean S. 2000. Some heavy metal and trace essential element detection in canned vegetable food stuff by differential pulse polarography (DPP). E- J. Environ. Agric. Food Chem., 4(2): 871-878.

Ozkutlu F, Sekeroglu N, Metin KS. 2006. Monitoring of cadmium and micronutrients in spices commonly consumed in turkey. Res. J. Agric Biol. Sci., 2(5): 223-226.

Tarley CRT, Coltro WKT, Matsushita M, de Souza NE. 2001. Characteristic levels of some heavy metals from Brazilian canned sardines (Sardinella brasiliensis). J. Food Comp. Anal., 14: 611-617.

Umar TM 2004. The determination of micro nutrients in some food items. J. Chem. Soc. Nigeria., 29(2): 159-161.

USEPA. 1984. Cost and benefit of reducing lead in gasoline Draft final Report Office of Policy Analysis. USEPA 230-03-84005, Washington D.C.

Zurera G, Estrada B, Rincon P, Pozo B. 1987. Lead and cadmium contamination levels in edible vegetables. Bull. Environ Contam. Toxicol., 42: 805-812. 